Trikonomika

Volume 16, No. 1, June 2017, Page. 8-20

ISSN 1411-514X (print) / ISSN 2355-7737 (online)

\title{
External and Internal Environment, and Business Ethic on Business Partnership and its Implication on Small Enterprise Performance in West Java
}

\author{
Tatang Suryana \\ tangsur510@gmail.com \\ BKPPMD West Java Province \\ Iman Sudirman \\ Ellen Rusliati
}

Doctoral Program of Management Science, Universitas Pasundan

\begin{abstract}
The purpose of this study is to obtain empirical evidence and find clarity on the phenomena about the influence of external and internal environment, and business ethic on business partnership and its impact on small enterprise performance in West Java on small stamped-batik business. The research was conducted by using descriptive and inductive method by taking sample of 116 companies using simple random sampling technique proportionally with structural equation model analysis. The conclusions obtained are that the external environment, and business ethic were in the fair category, while the internal environment, partnership, and performance were good. SEM analysis showed that the external and internal environment, and business ethic simultaneously had positive and significant effect on partnership of $64.6 \%$. Partially, the external environment had positive and significant impact on the business partnership of $15.41 \%$. The internal environment had a positive and significant impact on business partnership of $28.73 \%$. Business ethic had a positive and significant effect on business partnership of 20.30\%. Business Partnership had a positive and significant impact on Small Enterprise Performance of $84.3 \%$.
\end{abstract}

Keywords: external environment, internal environment, business ethic, business partnership, small enterprise performance.

\section{INTRODUCTION}

The 21 st century economy is characterized by economic globalization affecting Indonesia's economic conditions. The role of small enterprises in West Java is very large, indicated by its contribution to the West Java economy and employment annually increased (Table 1). These conditions and facts are in line with the empirical results by Demirbag et al. (2006) that concludes the success of small enterprises has a direct impact on economic development in both developed

\begin{tabular}{ccc}
\multicolumn{3}{c}{$\begin{array}{c}\text { Table 1. Distribution of Small Enterprises to West Java } \\
\text { Economy and Employment Absorption }\end{array}$} \\
\hline Year & $\begin{array}{c}\text { Small Business Distribution } \\
\text { to West Java economy (\%) }\end{array}$ & Employment \\
\hline 2008 & 43,81 & 10.757 .794 \\
2009 & 44,21 & 11.319 .397 \\
2010 & 44,30 & 11.132 .349 \\
\hline
\end{tabular}

Source : Kajian Peran KUMKM terhadap Perekonomian Jawa Barat, Dinas KUMKM Provinsi Jawa Barat dan BPS Provinsi Jawa Barat, 2011 and developing countries. Small businesses have the ability to create jobs at minimum cost, are pioneers in the world of innovation and have high flexibility that enables such businesses to meet customer needs.

West Java Provincial Government pays full attention to the empowerment and development of small business by issuing West Java Provincial Regulation No. 10 of 2010 on Empowerment and Development of Cooperatives, Micro, Small and Medium Enterprises. The Regional Regulation states that small businesses have a strategic position and role to improve the regional economy.

One of the small business products that have received world recognition is batik. Indonesian Batik in terms of techniques, technology, and development of motives and culture has been established as Masterpieces of the Oral and Intangible Heritage of Humanity by the United Nations Educational, Scientific and Cultural Organization (UNESCO ) On October 2, 2009.

A small stamped-batik business need to get attention and guidance, among others through small or large business partnerships and other financial institution partnerships in the form of cooperation network to form a healthy 
and coordinated trading ethic, in addition to motivate the struggling small business in the hope to achieve performance effectively and efficiently with maximum, realistic and rational results (Suryana: 2003: 50).

Wheelen, et.al. (2015: 49) classifies the external environment into two categories, namely the societal environment and the task environment. Societal environment is a strength that indirectly touches organizational activities in short term, but can influence organizational decisions in long term. The societal environment involves economic strength, technological strength, the strength of local government policy, and socio-cultural strength. Task environment is an element or a group that directly affect the company, including government, local communities, competitors, customers, creditors, unions / workers, interested groups and trade associations.

Based on preliminary survey that has been conducted on 100 small stamped-batik businesses, an average of $36 \%$ of respondents states that the external environmental condition is in good condition. (Table 2).

Table 2. External Environment of Small Stamped-Batik Business in West Java

\begin{tabular}{|c|c|c|c|c|c|c|}
\hline No & $\begin{array}{c}\text { External } \\
\text { Environment }\end{array}$ & $\begin{array}{l}\text { Very } \\
\text { Good }\end{array}$ & Good & Fair & $\mathrm{Bad}$ & $\begin{array}{l}\text { Very } \\
\text { Bad }\end{array}$ \\
\hline 1 & $\begin{array}{l}\text { Economic } \\
\text { conditions }\end{array}$ & $5 \%$ & $10 \%$ & $25 \%$ & $40 \%$ & $20 \%$ \\
\hline 2 & $\begin{array}{c}\text { Technology } \\
\text { owned }\end{array}$ & $0 \%$ & $10 \%$ & $41 \%$ & $29 \%$ & $20 \%$ \\
\hline 3 & $\begin{array}{c}\text { Local government } \\
\text { policy on small } \\
\text { business }\end{array}$ & $5 \%$ & $17 \%$ & $43 \%$ & $27 \%$ & $8 \%$ \\
\hline \multirow[t]{2}{*}{4} & Social factors & $7 \%$ & $33 \%$ & $35 \%$ & $20 \%$ & $5 \%$ \\
\hline & Average & $4,25 \%$ & $17,5 \%$ & $36 \%$ & $29 \%$ & $13,25 \%$ \\
\hline
\end{tabular}

Based on the preliminary survey conducted on 100 small stamped-batik businesses, it is found that the internal environmental condition is in good condition, on average of $35.33 \%$. (Table 3 ).

Table 3. Internal Environment of Small Stamped-Batik Business in West Java

\begin{tabular}{ccccccc}
\hline No & $\begin{array}{c}\text { External } \\
\text { Environment }\end{array}$ & $\begin{array}{c}\text { Very } \\
\text { Good }\end{array}$ & Good & Fair & Bad & $\begin{array}{c}\text { Very } \\
\text { Bad }\end{array}$ \\
\hline 1 & $\begin{array}{c}\text { Resources } \\
\text { owned } \\
\text { Organizational } \\
\text { culture }\end{array}$ & $8 \%$ & $12 \%$ & $25 \%$ & $40 \%$ & $15 \%$ \\
3 & Structure & $12 \%$ & $20 \%$ & $42 \%$ & $15 \%$ & $11 \%$ \\
\hline & Average & $9 \%$ & $19,33 \%$ & $35,33 \%$ & $23,67 \%$ & $12,67 \%$ \\
\hline Source : pre survey & & & & $16 \%$ & $12 \%$ \\
\end{tabular}

Source : pre survey
West Java Provincial Government issues the Regulation No. 8 of 2011 on Management of Revolving Funds for Small and Micro Enterprises as one effort to empower small businesses that in its implementation regulates West Java Governor Regulation No. 57 of 2011 on Guidelines for Implementation of Regional Regulation No. 8 of 2011 on Revolving Fund Management for Micro and Small Business. The success of business partnerships is determined by the compliance among partners in running their business ethic (Hafsah, 2000: 43). Participants who are directly involved in the partnership must have a foundation of business ethic that is understood and shared as a starting point in running the partnership. Based on the preliminary survey, it is found that the implementation of business ethic of small stamped-batik business is good with an average value of $32.2 \%$ (Table 4 ).

Table 4. Business Ethic of Small Stamped-Batik Business in West Java

\begin{tabular}{ccccccc}
\hline No & $\begin{array}{c}\text { External } \\
\text { Environment }\end{array}$ & $\begin{array}{c}\text { Very } \\
\text { Good }\end{array}$ & Good & Fair & Bad & $\begin{array}{c}\text { Very } \\
\text { Bad }\end{array}$ \\
\hline 1 & $\begin{array}{c}\text { Autonomy } \\
\text { principle }\end{array}$ & $12 \%$ & $34 \%$ & $23 \%$ & $21 \%$ & $10 \%$ \\
2 & $\begin{array}{c}\text { Principle of } \\
\text { honesty } \\
\text { Principle of } \\
\text { fairness }\end{array}$ & $22 \%$ & $24 \%$ & $33 \%$ & $16 \%$ & $5 \%$ \\
3 & $\begin{array}{c}\text { Principle } \\
\text { of mutual } \\
\text { benefit }\end{array}$ & $5 \%$ & $44 \%$ & $20 \%$ & $20 \%$ & $11 \%$ \\
& $\begin{array}{c}\text { Principle } \\
\text { of moral } \\
\text { integrity }\end{array}$ & $16 \%$ & $30 \%$ & $16 \%$ & $23 \%$ & $15 \%$ \\
\hline Average & $14,4 \%$ & $32,2 \%$ & $23 \%$ & $19,8 \%$ & $10,6 \%$ \\
\hline Source : pre survey & & & & $12 \%$ & \\
\hline
\end{tabular}

Failure of partnership is generally due to the foundation of a less powerful partnership and based solely on compassion or on the basis of coercion of others, not on the basis of the need to move forward and developing together from parties in partnership. Partnerships that are not based on good business ethic (values, morals, attitudes and behavior) can cause the partnership to not work well. The conclusion of the above description considering the running of a small business partnership is dependent on equality of values, morals, attitudes and behavior of partners. The success of business partnerships depends on the existence of organizational cultural equality (Hafsah, 2000: 87). 
Table 5. Partnership Profile of Small Stamped-Batik Businesses in West Java Province, 2009-2010

\begin{tabular}{ccccc}
\hline Category & $\mathbf{2 0 0 9}$ & Percentage & $\mathbf{2 0 1 0}$ & Percentage \\
\hline $\begin{array}{c}\text { Number of Small } \\
\text { business }\end{array}$ & 207 & 100 & 207 & 100 \\
$\begin{array}{c}\text { No Partnership } \\
\text { Establish }\end{array}$ & 72 & 34,78 & 69 & 33,33 \\
$\begin{array}{c}\text { partnership } \\
\text { Loan money/capital }\end{array}$ & 135 & 65,23 & 138 & 66,67 \\
\hline goods & 135 & 100 & 135 & 100 \\
Marketing & 108 & 80 & 126 & 93,33 \\
Business guidance & 121 & 89,63 & 116 & 85,92 \\
$\quad$ Others & 127 & 94,07 & 124 & 91,85 \\
\hline Source Dimis Koperasi Usaha
\end{tabular}

Source : Dinas Koperasi Usaha Mikro Kecil dan Menengah Provinsi Jawa Barat dan Profil Usaha Mikro dan Kecil, BPS, 2011 and 2012 (processed)

Table 5 shows that from 2009 to 2010 that there has been an increase in small stamped-batik businesses that have established partnerships. Types of capital loan partnerships have not changed, partnership in marketing increased, business guidance and other partnership decreased. Rudberg and Olhager (2003: 29) stated that the main goal of business partnership is to improve competitiveness and performance for all partners.

Company performance is an obsession that always strives in the achievement of an organization. Performance is one of the important achievements as a measure of the success rate of the organization. Performance achievement within the company is expected to be achieved proportionately.
The financial performance of small stamped-batik businesses in West Java in 2009 to 2011 is guided by the Regulation of the State Minister of Cooperatives and MSME No. 06/Per/M.KUMKM/V/2006. Table 6 illustrates the average financial performance of stampedbatik business in West Java is not yet optimal. This can be seen in the solvency ratio that shows the less healthy criteria, Asset Turn Over (ATO) is very unhealthy and the receivable turnover ratio is still in the very unhealthy category.

The performance of small stamped-batik business in West Java that partnered with SOEs is, viewed from a financial perspective, not yet optimal. Based on the preliminary survey, viewed from the perspective of the customer, shows that the average quality of service, customer satisfaction on the product, and market share is quite good, the average market share is $30-40 \%$, and the market growth is $2-5 \%$ per year. The internal business process perspective, showing the average administrative system, the level of customer productivity, and the product quality are quite good. Relating to the learning and growth perspective shows that employee's operational skills, employee commitment to business development, technology use, entrepreneurship ability, and product innovation capability are quite good. It's just that this ability can be optimized again in improving small enterprise performance in West Java is also directed to the use of technology and product innovation capabilities by involving practitioners, entrepreneurs and universities. Small businesses in West Java show a lot of interaction with outsiders, such as product exhibition by the government, communication with suppliers, consumers, KADIN, and various associations.

Table 6. Average Financial Performance of Small Stamped-Batik Businesses in West Java, 2009-2011

\begin{tabular}{|c|c|c|c|c|c|}
\hline \multirow{2}{*}{ Ratio } & \multirow{2}{*}{ Standard } & \multirow{2}{*}{ Criteria } & \multicolumn{3}{|c|}{ Year } \\
\hline & & & 2009 & 2010 & 2011 \\
\hline 1. Liquidity Ratio & $175-<200$ & Healthy Enough & $188,41 \%$ & $176,42 \%$ & $169,83 \%$ \\
\hline \multicolumn{6}{|l|}{ 2. Solvency Ratio: } \\
\hline a. Total Debt to Asset & $>50 \%-60 \%$ & Unhealthy & $49,70 \%$ & $52,58 \%$ & $55,36 \%$ \\
\hline b. Total Debt to Own Capital & $>150 \%-200 \%$ & Unhealthy & $198,8 \%$ & $160,90 \%$ & $124,05 \%$ \\
\hline \multicolumn{6}{|l|}{ 3. Profitability Ratio: } \\
\hline a. Net Profit Margin & $>15 \%$ & Healthy & $63,98 \%$ & $59,53 \%$ & $50,08 \%$ \\
\hline b. Return on Asset & $>10 \%$ & Healthy & $16,13 \%$ & $14,80 \%$ & $14,81 \%$ \\
\hline c. Asset Turn Over & $<1$ time & Very Unhealthy & 0,25 kali & 0,24 kali & 0,24 kali \\
\hline d. Own Capital Profitability & $>21 \%$ & Healthy & $32 \%$ & $31,2 \%$ & $33,19 \%$ \\
\hline \multicolumn{6}{|l|}{ 4. Activity Ratio: } \\
\hline Receivable turnover & $<6$ times & Very Unhealthy & 0,44 kali & 0,58 kali & 0,62 kali \\
\hline
\end{tabular}

Source: Dinas Koperasi, Usaha Mikro, Kecil dan Menengah Provinsi Jawa Barat/Bidang Kemitraan dan Pengembangan Produk $U M K M$ (processed) 
The formulation of research problem are: (1) How is the external and internal environment, and business ethic, partnership and performance of small stampedbatik business in West Java, (2) How much influence of external and internal environment, and business ethic, simultaneously and partially to business partnership on small stamped-batik business in West Java, (3)
How much influence of business partnership on the performance of small stamped-batik business in West Java. The research paradigm is shown in Figure 1.

Hypothesis proposed: (1) External environment, internal environment and business ethic simultaneously and partially affect the business partnership, (2) Business partnership affect the performance of small enterprise.

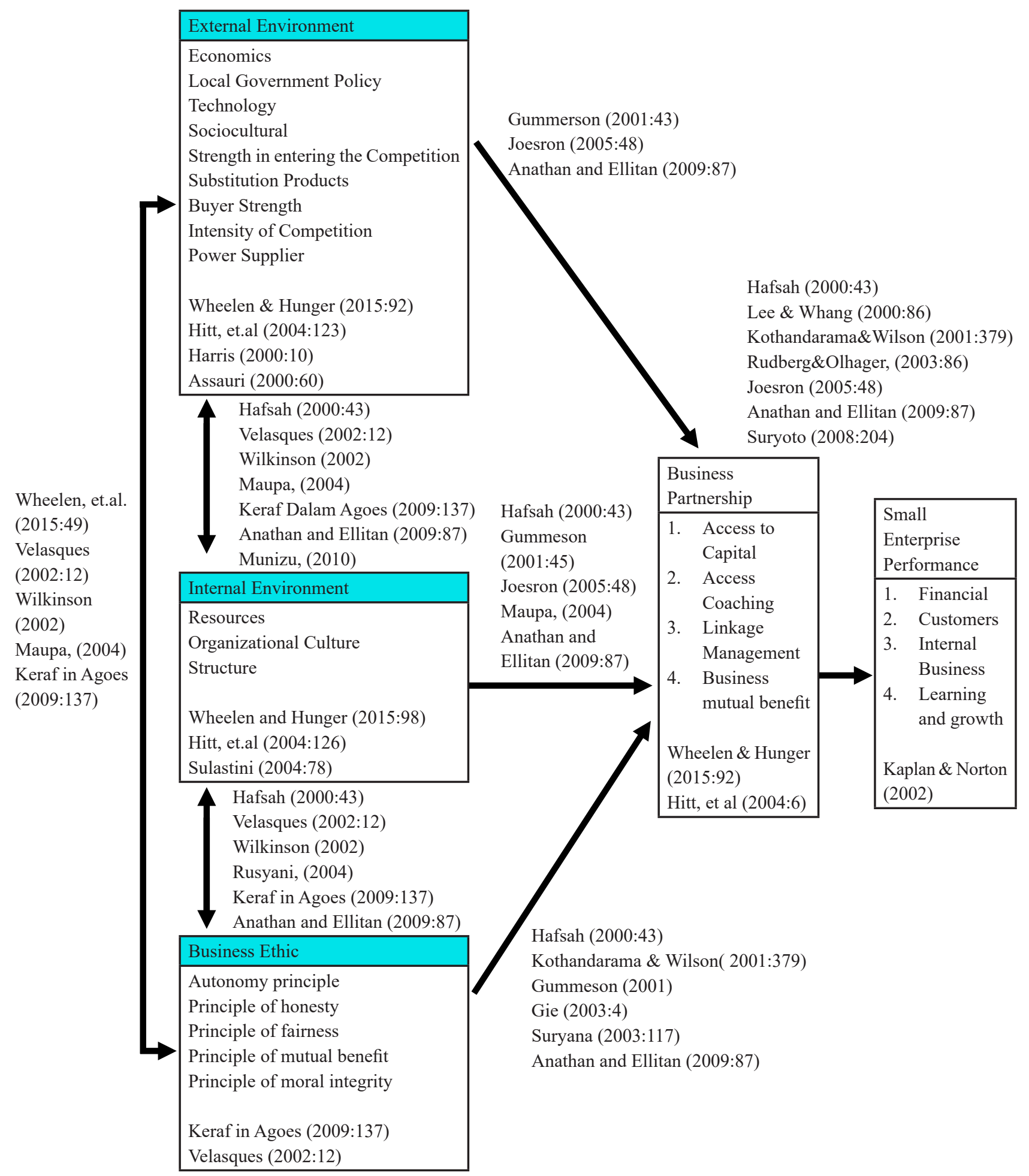

Figure 1. Research Paradigm 


\section{METHODS}

The research method used was survey, using descriptive and verificative structural equation model (SEM) analysis. This study was conducted on a number of small stamped-batik businesses based on Law No. 20 of 2008 in West Java with top management respondents of the company. Location of small stamped-batik business spread in regencies/cities in West Java. The data used were primary and secondary. Primary data was obtained by coordinating three data collection techniques, namely interview, observation and questionnaire. Questionnaires were tested with validity and reliability. Secondary data was obtained from Central Bureau of Statistics of West Java Province, Department of Industry and Trade of West Java Province, Department of Cooperatives, Micro, Small and Medium Enterprises of West Java Province, Regional Agency of Regency/City Industry and Trade of West Java, Promotion and Investment Coordinating Board of West Java Province, Regional Agency of Regency/ City in the field of Investment and Licensing in West Java, Batik Foundation of West Java, universities, and other private institutions.

The populations were 207 small stamped-batik businesses based on the activity of the company to submit annual business and investment report 20072012 (Table 7) with cluster proportional random sampling. The minimum sample size was determined by the Taro Yamane formula with a significance level of 5\% (Wijayanto, 2007: 45) that was 116.

\begin{tabular}{clccc}
\multicolumn{5}{c}{ Table 7. Sample Size by Regency/City } \\
\hline No & Regency/City & Population & Calculation & $\begin{array}{c}\text { Number of } \\
\text { Sample }\end{array}$ \\
\hline 1 & Bogor Regency & 1 & $(1 / 207) \times 116$ & 1 \\
2 & Depok City & 4 & $(4 / 207) \times 116$ & 2 \\
3 & Cianjur Regency & 3 & $(3 / 207) \times 116$ & 2 \\
4 & Bekasi Regency & 2 & $(2 / 207) \times 116$ & 1 \\
5 & Karawang Regency & 1 & $(1 / 207) \times 116$ & 1 \\
6 & Cirebon Regency & 100 & $(100 / 207) \times 116$ & 57 \\
7 & Cirebon City & 4 & $(4 / 207) \times 116$ & 2 \\
8 & Indramayu Regency & 30 & $(30 / 207) \times 116$ & 16 \\
9 & Kuningan Regency & 1 & $(1 / 207) \times 116$ & 1 \\
10 & Bandung City & 20 & $(20 / 207) \times 116$ & 10 \\
11 & Bandung Regency & 3 & $(3 / 207) \times 116$ & 2 \\
12 & Cimahi City & 6 & $(6 / 207) \times 116$ & 4 \\
13 & Sumedang Regency & 2 & $(2 / 207) \times 116$ & 1 \\
14 & Garut Regency & 10 & $(10 / 207) \times 116$ & 5 \\
15 & Tasikmalaya Regency & 10 & $(10 / 207) \times 116$ & 5 \\
16 & Tasikmalaya City & 5 & $(5 / 207) \times 116$ & 3 \\
17 & Ciamis Regency & 5 & $(5 / 207) \times 116$ & 3 \\
\hline & Total & 207 & - & 116 \\
\hline Source & $:$ Tanda Daftar & & 5 \\
\hline
\end{tabular}

Source : Tanda Daftar Perusahaan Dinas Perindustrian dan Perdagangan Kab/Kota se Jabar 2007-2012, Dinas KUMKM Provinsi Jawa Barat (processed)
The model feasibility test used the goodness of the econometric model criteria. According to Koutsoylannis in Ghozali (2008: 38), feasibility testing model must meet the criteria of (1) Theoretical plausibility, (2) Accuracy of The Estimates of The Parameters, (3) Explanatory Ability, (4) Forecasting Ability.

\section{RESULTS}

Batik business centers were spread spatially in five areas of Bogor, Purwakarta, Cirebon, East Priangan and West Priangan. The distribution was concentrated in Cirebon and East Priangan area.

Table 8. Distribution of Number of Batik Business Center in West Java 2010

\begin{tabular}{lc}
\hline \multicolumn{1}{c}{ Region } & Total Center (\%) \\
\hline Bogor & $3,36 \%$ \\
Purwakarta & $1,44 \%$ \\
Cirebon & $40,62 \%$ \\
Priangan Timur & $18,75 \%$ \\
Priangan Barat & $10,09 \%$ \\
\hline
\end{tabular}

Descriptive analysis of each variable is summarized in Table 9.

Table 9. Distribution of Number of Batik Business Center in West Java 2010

\begin{tabular}{rlcc}
\hline No & \multicolumn{1}{c}{ Variable } & Average \pm stdev & \multicolumn{1}{c}{ Result } \\
\hline 1 & $\begin{array}{l}\text { External } \\
\text { Environment }\end{array}$ & $3,69 \pm 0,32$ & Medium to High \\
2 & $\begin{array}{l}\text { Internal } \\
\text { Environment }\end{array}$ & $4,13 \pm 0,16$ & High to Very High \\
3 & $\begin{array}{l}\text { Business } \\
\text { Ethic }\end{array}$ \\
4 & $\begin{array}{l}\text { Business } \\
\text { Partnership }\end{array}$ & $3,19 \pm 0,20$ & High to Very High \\
5 & $\begin{array}{l}\text { Small Enterprise } \\
\text { Performance }\end{array}$ & $3,65 \pm 0,27$ & Medium to High \\
\hline
\end{tabular}

Source : Data processing

The external environment was measured by 9 dimensions: Economics, Local Government Policy, Technology, Sociocultural, Strength in entering competition, Substitution product, Strength of buyer, Intensity of competition, Supplier strength. Indicators that show below average value were: (1) Interest rate condition (2) Impact of Unemployment Rate on company activity, (3) Influence of company's budget support in company's technology research and development, (4) Wage system determined by government.

The internal environment was measured by 3 dimensions: resources, culture and structure. Indicator that showed the value below the average was company 
that has adequate human resources. The results of this study were in line with Sutopo's statement (2011:102) that micro issues of small business are faced with internal problems such as low human resources (less skilled, low entrepreneurship, lack of technology, lack of management and market domination).

Business ethic was measured by 5 dimensions: economic principle, principle of honesty, principle of fairness, principle of mutual benefit and principle of moral integrity. Indicator that showed the value below the average was company that provides benefits for the community.

Business partnership was measured by 4 dimensions: access to capital, guidance, management linkages, and mutually beneficial business. The smallest average value of the profits obtained was in line with the company's objectives.

Business performance was measured by 4 dimensions: financial perspective, customer perspective, internal business perspective, learning and growth perspective. The smallest average values were: (1) all this time the company always receives complaints from customers, and (2) the company always tries to acquire new customers.

Analysis of Constructive variables is as in Figure 2.
The explanation of the CFA measurement model for each variable relationship and its indicator are as follows:

1. External Environment Variable $\left(\zeta_{1}\right)$ : the largest loading factor value in sociocultural dimension $\left(\mathrm{X}_{14}, \zeta_{1}\right)$ was 0,712 with a forming influence of $50.7 \%$.

2. Internal Environment Variable $\left(\zeta_{2}\right)$ : the largest loading factor value in cultural dimension $\left(\mathrm{X}_{22}, \zeta_{2}\right)$ was 0,761 with a forming influence of $57,9 \%$.

3. Business Ethic Variable $\left(\zeta_{3}\right)$ : the largest loading factor value in principle of fairness dimension $\left(\mathrm{X}_{33}, \zeta_{3}\right)$ was 0,672 with a forming influence of $45,2 \%$.

4. Business Partnership Variable $\left(\eta_{1}\right)$ : the largest loading factor value in guidance dimension $\left(\mathrm{Y}_{12}, \eta_{1}\right)$ was 0,664 with a forming influence of $44,1 \%$.

5. Small Enterprise Performance Variable $\left(\eta_{2}\right)$ : the largest loading factor value in learning and growth perspective dimension $\left(Z_{14}, \eta_{1}\right)$ were 0,661 with a forming influence of $43,6 \%$.

The structural model that described the influence of external and internal environment, and business ethic

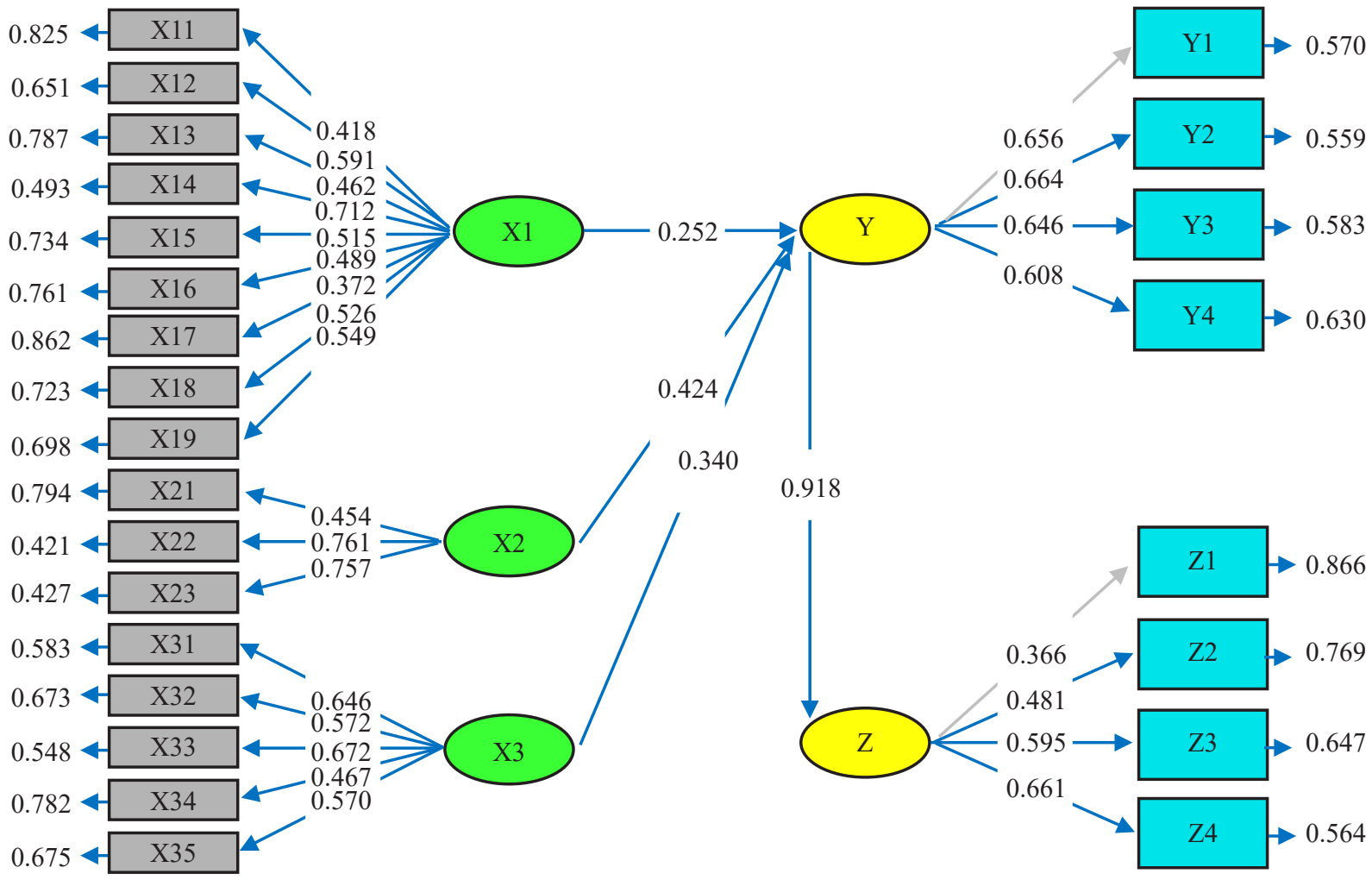

Source: Lisrel 8.7

Figure 2. Structure of All Variables Relationship 
on partnership is expressed in the structural equation model of sub structural 1 , as followed:

$$
\begin{array}{lcc}
Y=0,252 * X_{1}+0,424 * X_{2}+0,340 * X_{3}, \text { Errorvar. }=0,354, R^{2}=0,646 \\
(0,124) & (0,129) & (0,115) \\
2,039 & 3,298 & 2,964
\end{array}
$$

Y : Partnership

$\mathrm{X} 1$ : External Environment

$\mathrm{X} 2$ : Internal Environment

$\mathrm{X} 3$ : Business Ethic

The above equation explains that external environment had a positive effect on business partnership (path coefficient of 0.252). Internal environment had a positive effect on business partnership (path coefficient of 0.424). Business ethic had a positive effect on business partnership (path coefficient of 0.340). Partnership was simultaneously affected by the external and internal environment, and business ethic by $64.6 \%$.

A complete structural model for substructure 1 could be described as follows:

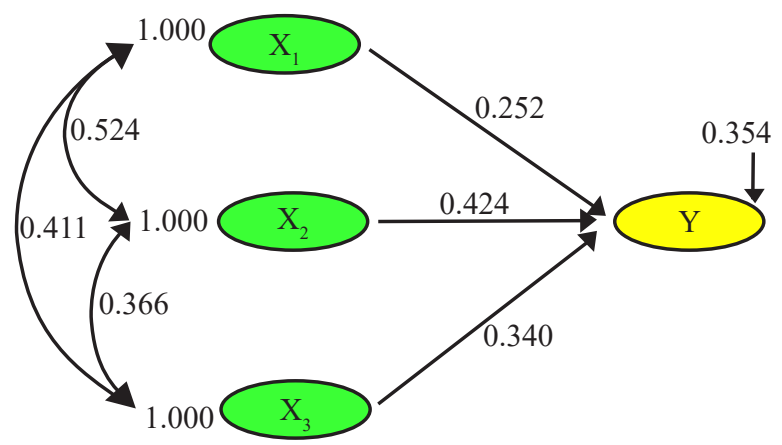

Figure 3. Path Coefficient of External and Internal Environment, and Business Ethic Variables on Partnership

Based on the correlation and path coefficient, it can be seen that the magnitude of direct and indirect influence of external and internal environment, and business ethic variables on partnership variable can be summarized in Table 8. The results reinforced the statement of Hitt, et. Al, translated by Armand (2004:123) that small business partnership was influenced by the role of the environment in which the business was carried out.
Structural model 2 illustrates the effect of partnership on small enterprise performance. The results of data processing yielded the following equation:

$$
\begin{aligned}
& \mathrm{Z}=0,918^{*} \mathrm{Y} \text {, Errorvar. }=0,157, \mathrm{R}^{2}=0,843 \\
& (0,276) \quad(0,154) \\
& 3,322 \quad 1,017
\end{aligned}
$$

$\mathrm{Z}$ : small enterprise performance

Y : business partnership

The above equation explains that small enterprise performance was positively influenced by partnership with path coefficient of 0.918 . The value of $R 2$ illustrates that small enterprise performance was influenced by business partnership by $84.3 \%$.

The results of hypothesis testing simultaneously showed that there was simultaneous influence of

\begin{tabular}{|c|c|c|c|c|}
\hline Structural & $\begin{array}{c}\text { Path } \\
\text { Coefficient }\end{array}$ & t-count & t-table & Conclusion \\
\hline$\gamma_{\mathrm{YX} 1}$ & 0,252 & 2,039 & 1,96 & $\begin{array}{l}\mathrm{H}_{0} \text { rejected, } \\
\text { there is a } \\
\text { significant effect } \\
\text { of external } \\
\text { environment on } \\
\text { partnership }\end{array}$ \\
\hline$\gamma_{\mathrm{YX} 2}$ & 0,424 & 3,298 & 1,96 & $\begin{array}{c}\mathrm{H}_{0} \text { rejected, } \\
\text { there is a } \\
\text { significant } \\
\text { effect of internal } \\
\text { environment on } \\
\text { partnership }\end{array}$ \\
\hline$\gamma_{\mathrm{YX} 3}$ & 0,340 & 2,964 & 1,96 & $\begin{array}{l}\mathrm{H}_{0} \text { rejected, } \\
\text { there is a } \\
\text { significant effect } \\
\text { of business ethic } \\
\text { on partnership }\end{array}$ \\
\hline
\end{tabular}
external and internal environment, and business ethic on business partnership. The results of partial hypothesis testing are shown in Table 9.

Table 9. Partial Test Results of External Environment $\left(\mathrm{X}_{1}\right)$, Internal Environment $\left(\mathrm{X}_{2}\right)$, Business Ethic $\left(\mathrm{X}_{3}\right)$ on Partnership $(\mathrm{Y})$

Source : processed data

Table 8. Direct and Indirect Influence of External and Internal Environment, and Business Ethic on Partnership

\begin{tabular}{ccccccc}
\hline \multirow{2}{*}{ Variable } & $\begin{array}{c}\text { Direct } \\
\text { Influence }\end{array}$ & $\begin{array}{c}\text { External } \\
\text { Environment }\end{array}$ & $\begin{array}{c}\text { Internal } \\
\text { Environment }\end{array}$ & Business Ethic & $\begin{array}{c}\text { Total Indirect } \\
\text { Influence }\end{array}$ & $\begin{array}{c}\text { Total } \\
\text { Influence }\end{array}$ \\
\cline { 3 - 6 } External Environment & $6,35 \%$ & & $5,54 \%$ & $3,52 \%$ & $9,06 \%$ & $15,41 \%$ \\
Internal Environment & $17,97 \%$ & $5,54 \%$ & & $5,22 \%$ & $10,76 \%$ & $28,73 \%$ \\
Business Ethic & $11,56 \%$ & $3,52 \%$ & $5,22 \%$ & & $8,74 \%$ & $20,30 \%$ \\
\hline Total & $35,88 \%$ & $9,06 \%$ & $10,76 \%$ & $8,74 \%$ & $28,56 \%$ & $\mathbf{6 4 , 6 \%}$ \\
\hline
\end{tabular}

Source : Data Processing Result 
The results of hypothesis test of partnership on small enterprise performance are shown in Table 10.

Table 10. Test Results of Partnership (Y) on Small Enterprise Performance $(\mathrm{Z})$

\begin{tabular}{|c|c|c|c|c|}
\hline Structural & $\begin{array}{c}\text { Path } \\
\text { Coefficient }\end{array}$ & t-count & t-table & Counclusion \\
\hline
\end{tabular}

\begin{tabular}{llllc}
\hline & & & $\begin{array}{c}\mathrm{H}_{0} \text { rejected, there is } \\
\text { a significant effect } \\
\text { of partnership on } \\
\text { small enterprise } \\
\text { performance }\end{array}$ \\
\hline
\end{tabular}

Source : processed data

The External Environment was formed by 9 (nine) dimensions with 28 indicators. The largest loading factor value in sociocultural dimension $\left(\mathrm{X}_{14}, \zeta_{1}\right)$ was 0.712 . The sociocultural indicators in this study were: (1) Lifestyle change with an average value of 3.87, (2) Consumer activity with an average value of 3.39, (3) Population growth rate with an average value of 3.44, (4) Migration with an average value of 3.42 , (5) Birth rate and life expectancy with an average value of 3.41 .

Thus the dominant indicator on the sociocultural dimension was lifestyle change.

The internal environment was formed by 3 (three) dimensions with 19 indicators. The largerst loading factor value in cultural dimension $\left(\mathrm{X}_{22}, \zeta_{2}\right)$ was 0.761 with a forming effect of $57.9 \%$. The indicators of cultural dimensions in this study were: (1) Business environment with an average value of 4.33, (2) Value with an average value of 4.41 , (3) Heroes with an average value of 4.28 , (4) Ceremonies and rituals were with an average value of 4.26, (5) Cultural network was with an average value of 4.16. The dominant indicator of cultural dimension was value. It can be understood that the value implanted to always be proud of using batik in everyday life makes a very strong factor forming a strong culture. Cultural use of batik from generation to generation, the use of batik in various activities both work and business and other activities as well as the inauguration of batik as world heritage by UNESCO are the things that affects the internal environment, and a very strong factor form a strong culture.

Business ethic was formed by 5 (five) dimensions with 17 indicators. The largest loading factor value in principle of fairness dimension $\left(\mathrm{X}_{33}, \zeta_{3}\right)$ was 0.672 with a forming effect of $45.2 \%$. The meaning of the value was that the principle of fairness had a very strong correlation to business ethic variable. The indicators of the principle of fairness dimension in this study were: (1) Does not distinguish the treatment according to the rules and objective rational criteria with an average value of 4.29 , (2) Gain equal opportunity in the selection of promotion of position with an average value of 4.32, (3) Gain equal opportunity in the selection of business partners with an average value of 4.43, (4) Proportional in the distribution of profit with an average value of 4.28. The dominant indicator of principle of fairness dimension was to gain equal opportunity in the selection of business partners.

Business partnership was formed by 4 (four) dimensions with 16 indicators. The largest loading factor value in guidance dimension $\left(\mathrm{Y}_{12}, \eta_{1}\right)$ was 0.664 with a forming effect of $44.1 \%$. The indicators of guidance dimension in this research were: (1) Training with an average value of 3.86 , (2) Comparative study with an average value of 3.56, (3) Internship with an average value of 3.59, (4) Mentoring/consultancy with an average value of 3.87. The most dominant indicator that formed the guidance dimension was training.

Business Performance was formed by 4 (four) dimensions with 20 indicators. The largest loading factor value in learning and growth perspective dimension $\left(Z_{14}, \eta_{1}\right)$ was 0.661 with a forming effect of $43.6 \%$. The meaning of the value was that the dimension of learning and growth perspective had a very strong correlation to the small enterprise performance variable. The indicators of learning and growth perspective dimension in this research were: (1) Competence and skill of employees with an average value of 3.63, (2) Information system competence with an average value of 3.78, (3) Motivation with an average value of 3.92. This study showed that the dominant indicator that made up the dimensions of the learning and growth perspective was motivational indicator.

Testing the hypothesis of external environment influence on business partnership showed that the external environment had a positive and significant impact on business partnership, meaning the better the external environment, the better the business partnership will be. The external environment provided a direct impact on business partnership of $6.35 \%$, while indirect influence through the internal environment was 5.54\% and through business ethic was $3.52 \%$. The effect of the external environment on the overall business partnership directly or indirectly amounted to $15.41 \%$.

Based on construct analysis the most dominant dimension on External Environment variable was sociocultural and the dominant indicator on sociocultural dimension was lifestyle change. Lifestyle change on the usage of batik to be a trend in everyday life is inseparable from the decision of the United Nations Educational, Scientific and Cultural Organization (UNESCO) on October 2, 2009. Indonesian batik viewed from the point of technique, technology, and development of motives and culture has been designated as Masterpieces of the Oral and Intangible Heritage of Humanity by UNESCO.

External Environment positively and significantly influenced Business Partnership, in accordance with expected theory and the opinion of Gummeson (2001: 88) that three stages of situation analysis had an effect on small business partnership/cooperative. The results of this study strengthen the research of Suryoto (2008) that had proven empirically there was an influence of external environment 
on business partnership with the object of research on small noodles business in Central Java. The results of research were in line with Anathan and Ellitan (2009: 87) stated that in order to achieve partnership success, companies must had confidence and belief on the relationships between business partners. Trust and professionalism must be maintained. The results of this study strengthen the results of Koza and Lewin (2000) research on partnerships and strategic alliances. In relation to environmental aspects, this study supported Wilkinson's (2002) research that small and micro enterprises would grow where the policy environment supported, macroeconomic environment was well managed, stable and predictable; reliable and accessible information, and the social environment encouraged and rewarded the success of the business.

The internal environment had a positive and significant impact on business partnership, meaning the better the internal environment, the better the business partnership will improve. The internal environment provided a direct impact on business partnership of $17.97 \%$, while the indirect effect through the external environment was 5.54\% and through business ethic was $5.22 \%$. The influence of the internal environment on the overall business partnership directly or indirectly amounted to $28.73 \%$.

Based on the construct analysis of the most dominant dimension variable in internal environment variable was cultural dimension. The dominant indicator of cultural dimension was value. It can be understood that the value implanted to always be proud of using batik in everyday life makes a very strong factor forming a strong culture. Cultural use of batik from generation to generation, the use of batik in various activities both work and business and other activities as well as the inauguration of batik as world heritage by UNESCO are the things that affects the internal environment, and a very strong factor form a strong culture.

The influence of the internal environment on the business partnership was in accordance with the expected theory and in line with Hafsah's statement (2000:43) that suggested that partnership was a series of processes that begin with knowing potential partners, knowing the position of advantages and weaknesses of its business that could be seen from its internal environment. The results of this study strengthen the opinion of Gummeson (2001: 88) that three stages of situation analysis affected the small business partnership/cooperative. The results of this study also strengthen the research by Suryoto (2008) that had proven empirically that there was an influence of the internal environment to business partnership with the object of research on small noodles businesses in Central Java.

The results of this study also strengthen Rizal K (2003) research that examined the influence of external and internal environment on human resource management functions in achieving company performance. This research was in line with Rahayu's (2004) research that examined the influence of micro power and internal environment on marketing strategy and its impact on the sales of clothing industry. The results of this research analysis also supported Sulastini's (2004) research on external and internal factors that influenced the success of small scale coal mining cooperative partnership that human resource capability positively affected the success of the partnership.

This study was also in line with the results of Pillay's (2006) research that showed the internal factors that hindered the growth of small business was the source of capital, financial knowledge, employee recruitment, and managerial skills.

Business ethic had a positive and significant impact on business partnership, meaning that the better business ethic, the better the business partnership would improve. The results were in accordance with the expected theory. Business ethic gave direct influence to business partnership of $11.56 \%$, while indirect influence through external environment was $3.52 \%$ and through internal environment was $5.22 \%$. The influence of business ethic on the overall business partnership directly or indirectly amounted to $20.30 \%$.

Based on analysis of variable construct, it indicated that the dominant factor to business ethic variable was dimension of principle of fairness. The dominant indicator of principle of fairness dimension was to gain equal opportunity in the selection of business partners. In choosing and establishing business partners in a business, it is not an easy thing. If it is wrong to determine the choice, it will also interfere with business programs, financial, and even the survival of small businesses. The selection of strategic partners aims to get partners for investment and business development. Partner selection is based on the ability to provide capital and experience in implementing the project. Both of these can only be obtained based on trust in the data and available capital and trust to the partner concerned.

The results of research showed the influence of business ethic on business partnership in accordance with the expected theory and supporting the statement of Hafsah (2000: 43) that the success of business partnerships was determined by the compliance among the partners in running their business ethic. Participants who are directly involved in the partnership must have the foundations of business ethic understood and shared as a starting point in running the partnership. This study was also in accordance with Wheelen's theory, et.al. (2015) that asserts that the principles that apply in good business could not be separated from the value system adopted by the company (corporate culture). The results of this research analysis also supported Keraf's statement in Bertens (2000: 35) stated that the success of business partnerships depended on the similarity of values, norms, attitudes and behaviors of actors who run the partnership, and the statement of Anathan and Ellitan (2009: 87) that achieving partnership success, companies must had confidence and belief that the relationships between their business partners were strategic assets of the company that must be seriously fostered. Trust 
and professionalism must be well preserved to produce mutually beneficial performance among various parties. The results also supported the statement of Kothandarama and Wilson (2001: 379) that to succeed a partnership must be based on business ethic.

External and internal environment and business ethic had significant effect on business partnership. This statement showed the better the management of external and internal environment and business ethic, the better the small business partnership will be. Based on the influence of each variable directly and indirectly indicated that external environment variable gave direct and indirect effect to business partnership by $15.41 \%$. Internal environment variable gave direct and indirect effect to business partnership by $28.73 \%$. Business ethic variable gave direct and indirect effect to business partnership by $20.30 \%$. The magnitude of influence of each independent variables on business partnership variable equal to $64,6 \%$.

Internal environment was the variable that gave dominant influence to business partnership by $28.73 \%$. The most dominant dimension was cultural dimension and the dominant indicator of cultural dimension was value. The value implanted to always be proud of using batik in everyday life makes a very strong factor forming a strong culture. Cultural use of batik from generation to generation, the use of batik in various activities both work and business and other activities as well as the inauguration of batik as world heritage by UNESCO are the things that affects the internal environment, and a very strong factor form a strong culture.

Based on the coefficient value of each independent variable path that was the external environment variable had a path coefficient of 0.252 . The internal environment variable had a path coefficient of 0.424 . The business ethic variable had a path coefficient value of 0.340 . The value of the path coefficient determined the action to be taken to improve the optimal business partnership. The greatest coefficient value gave a large effect on business partnership enhancement. The conclusion of the path coefficient value is to improve the business partnership optimally, the internal environment must first be enhanced and be a special concern.

The results of this study indicated that there was a simultaneous influence of external and internal environment, and business ethic toward business partnership, supporting and in line with research of Suryoto (2008) that proved empirically there was influence of external and internal environment simultaneously to business partnership with object of research on small noodles businesses in Central Java. The results of this research analysis also supported Sulastini's (2004) research on external and internal factors that influenced the success of small scale coal mining cooperative partnership, where external and internal factors simultaneously affected the success of partnership. The results of this study reinforced the results of Mirza's (2011) research that examined the influence of external and internal environment on competitive strategy and partnership strategies and their impact on competitive advantage and their implications on the performance of small and medium-sized industries in West Sumatra. The results showed that (1) external and internal environment had an effect on the Community Satisfaction Index (CSI) competing strategy simultaneously, where the internal environment had a dominant influence on CSI competing strategy, (2) external and internal environment affected the CSI partnership strategy simultaneously, where the internal environment had a dominant influence on CSI partnership strategy (3) external and internal environment with competitive strategy, and partnership strategy, had an effect on CSI competitiveness simultaneously (4) external and internal environment with competitive strategy, partnership strategy, and competitive advantage influenced CSI performance simultaneously.

Business partnership had a positive and significant impact on small enterprise performance that meant the better business partnerships, the better small enterprise performance will improve. Business partnership significantly influenced small enterprise performance by $84.3 \%$. The dominant factor of this business partnership variable was guidance dimension. The most dominant indicator that formed the guidance dimension was training.

Education and training programs are able to act as a trigger in organizational change or the achievement of the goals set, because with education and training mean encouraging HR to deliver a significant change in the future. Characteristics that are considered concrete of education and training programs in improving the quality of personnel performance is always evolving as the needs of the organization of work and the community is always changing. Potential forces that can cause change are interrelated. Education and training of various field or profession carried out with the aim of improving skills, knowledge and professionalism of employees in order to obtain optimal performance.

The results of this study indicated that there was a significant effect of business partnership on small enterprise performance in accordance with expected theory and supported the statement of Hafsah (2000:43), Anathan and Ellitan (2009:87), Lee and Whang (2000:86), Kothadarama and Wilson (2001:379), Rudberg and Olhager (2003:86).

Anathan and Ellitan (2009:87) stated that the success of a partnership would improve the performance of each company. Partnership can contribute to the achievement of competitive advantage in overall business networks that will ultimately improve the performance of partner companies (Rudberg and Olhager, 2003:86). In line with the statement, Dwi Kartini Yahya in Joesron (2005:48) stated that cooperatives or non-cooperative companies would be more synergic when approaching the business through an integrated partnership that can achieve superior organizational performance results that can provide satisfaction for all actors involved (stakeholders). The results of this study were in line with the above three statements. 
The results of this study were also consistent with research of Sulistyo and Adiatma (2011) that the partnership program in terms of access and additional capital, business management, use of technology, patents and constraints faced by both parties in the partnership. Partnership of SOEs and SMEs in terms of internal factors was quite good, as indicated by the knowledge of business management have better understanding of consumer knowledge, knowledge of effective promotion, have the knowledge to formulate a marketing strategy, financial administration and accounting skills as well as having a good innovation capability. All of them are positively correlated with improvements in innovation and performance. Business partnership and SME in terms of external factors were quite good. The results of correlation analysis between the barriers partnership with the performance of SME, SME who have little experience of the partnership and the ability of SMEs to solve financial problems went well, had a significant and positive impact on the performance of SME.

The model feasibility test results demonstrated that research model had met the criteria of the goodness of an econometric model. The study model showed that the test results was in accordance with expectations and strategy management theory as the rationale for the study of the influence of external and internal environment, and business ethic on partnership and its impact on small enterprise performance (theoretical plausibility).

Table 11. Theory Conformity Test Results

\begin{tabular}{|c|c|c|c|}
\hline $\begin{array}{c}\text { Relationship } \\
\text { between Variables }\end{array}$ & $\begin{array}{c}\text { Pre } \\
\text { Estimation }\end{array}$ & $\begin{array}{c}\text { Post } \\
\text { Estimation }\end{array}$ & Conformity \\
\hline $\begin{array}{l}\text { The influence } \\
\text { of external } \\
\text { environment on } \\
\text { partnership }\end{array}$ & + & + & Corresponding \\
\hline $\begin{array}{l}\text { The influence of } \\
\text { internal environment } \\
\text { on partnership }\end{array}$ & + & + & Corresponding \\
\hline $\begin{array}{l}\text { The influence of } \\
\text { business ethic on } \\
\text { partnership }\end{array}$ & + & + & Corresponding \\
\hline $\begin{array}{l}\text { The influence of } \\
\text { partnership on } \\
\text { small enterprise } \\
\text { performance }\end{array}$ & + & + & Corresponding \\
\hline $\begin{array}{l}\text { The influence of } \\
\text { external and internal } \\
\text { environment, and } \\
\text { business ethic } \\
\text { on partnership } \\
\text { and its impact on } \\
\text { small enterprise } \\
\text { performance }\end{array}$ & + & + & Corresponding \\
\hline
\end{tabular}

This research model yielded an accurate or unbiased and significant path coefficient estimator (Accuracy of The Estimates of The Parameters). The assumption of the analysis was met and the probability of statistical error of the model was very low $(p$-value $=0,000)$. This research model had a high ability in explaining the relationship between the phenomenons of management variables studied (explanatory ability). Standard Error (SE) was less than $1 / 2$ times the absolute value of its path coefficient $(\mathrm{SE}<1 / 2 \rho)$.

a. Hypothesis 1 Test Result:

There is an influence of External and Internal Environment, and Business Ethic on Partnership

SE External Environment $=0,124<1 / 2(0,252)$

SE Internal Environment $\quad=0,129<1 / 2(0,424)$

SE Business Ethic $\quad=0,115<1 / 2(0,340)$

b. Hypothesis 2 Test Result:

There is an influence of Partnership on Small Enterprise Performance

SE Partnership $\quad=0,276<1 / 2(0,918)$

This research model had a high predictive ability over the dependent variable behavior as indicated by the high coefficient of determination model approaching or exceeding 50\% (forecasting ability) with the following details: (1) The influence of external and internal environment, and business ethic towards partnership was $64.6 \%$, (2) The influence of partnership to small enterprise performance was equal to $84,3 \%$. This means that the model had complied with the goodness of the econometric criteria based on a strong theoretical perspective to contribute to the development of knowledge and for policy or problem solving.

\section{CONCLUSION}

Based on the analysis results, it can be concluded that:

1. The results of descriptive analysis provide information:

a. The external environment showed fair to good/high level category and the indicators that had low average value were the condition of interest rate, the impact of unemployment rate on corporate activity and the government's certainty in setting up the wage system.

b. The internal environment showed good/high to very good/very high level category and indicator that had low average value was adequate human resources owned by the company.

c. Business ethic showed good/high to very good/ very high level category and indicator that had low average value was about the benefits and corporate responsibility for the community.

d. Partnership showed fair to good/high level category and indicator that had low average value was about the level of profits obtained by 
the company was in accordance with corporate objectives.

e. Small enterprise performance indicated fair to good/high level category and indicators that had low average value were that the company always received complaints from customers as well as the company was always trying to acquire new customers.

2. The results showed that the external and internal environment and business ethic simultaneously had a positive and significant influence on Partnership variable by $64.6 \%$. The external environment partially had a positive and significant influence on business partnership by $15.41 \%$, the most dominant dimension was with the most dominant indicator was lifestyle changes. The internal environment partially had a positive and significant influence on business partnership by $28.73 \%$, the most dominant dimension was organizational culture with the most dominant indicator was value. Business ethic partially had a positive and significant influence on business partnership by $20.30 \%$, the most dominant dimension was the principle of fairness with the most dominant indicator was obtaining equal opportunity in the selection of business partners.

3. Business partnership had a positive and significant effect on small enterprise performance by $84.3 \%$, the most dominant dimension was guidance with the most dominant indicators is education and training.

\section{REFERENCES}

Agoes, Soekrisno dan I Cenik Ardana. 2009. Etika Bisnis dan Profesi: Tantangan Membangun Manusia Seutuhnya. Salemba Empat. Jakarta.

Anathan, Lina dan Ellitan, Lena. 2009. Supply Chain Management : Teori dan Aplikasi. Alfabeta. Bandung.

Badan Pusat Statistik. 2009. Jawa Barat Dalam Angka 2008. BPS Jawa Barat. Bandung.

2013. Jawa Barat Dalam Angka

2012. BPS Jawa Barat. Bandung. 2011. Profil Usaha Mikro dan

Kecil 2009. BPS RI. Jakarta.

Kecil 2010. BPS RI. Jakarta.

- 2012. Statistik Indonesia. BPS

RI. Jakarta.

Demirbag, M., Tatoglu, E., Tekinkus, M. and Zaim,S., 2006, "An analysis of the relationship between TQM implementation and organizational performance: evidence from Turkish SMEs", Journal of Manufacturing Technology Management, Vol. 17 No. 6, pp. 829-47.

Dinas Perindustrian dan Perdagangan Provinsi Jawa
Barat, 2011. Laporan Tahunan Dinas Perindustrian dan Perdagangan Provinsi Jawa Barat Tahun 2010. Dinas Indag Jabar. Bandung.

Dinas Koperasi Usaha Mikro Kecil dan Menengah Provinsi Jawa Barat dan BPS Provinsi Jawa Barat, Bandung. 2011. Kajian Peran KUMKM terhadap Perekonomian Jawa Barat. Dinas KUMKM Jabar. Bandung.

Gie, Kwik Kian. 2003. Kebijakan Ekonomi Pemerintah RI: Tinjauan Etika Bisnis. Makalah Forum Munas Tarjih ke-26 PP Muhammadiyah di Padang.

Gummeson, Evert. 2001. Total Relationship Marketing. Butter-worth Heinemann.

Hafsah, Muhammad Jafar. 2000. Kemitraan Usaha. Pustaka Sinar Harapan. Jakarta.

Hitt, Michael A, R Duane Ireland \& Robert E. Hoskisson. 2004. Manajemen Strategis : Menyongsong era Persaingan dan Globalisasi. Alih bahasa oleh Armand Adiyanto. Erlangga. Jakarta.

Joesron, Tati Suhartati. 2005. Manajemen Strategik Koperasi. Graha Ilmu. Yogyakarta.

Kothandarama, P.\& Wilson, D.T. 2001. The Future of Competition: Value Creating Networks. Industrial Marketing Management : p 30, 379.

Koza, Mitchell and Lewin, Aril. 2000. Managing Partnership and Strategic Alliances : Raising The Adds of Success European Management, Journal Vol: 16 No.2.

Lee, H.L \& Whang, D. 2000. Information Sharing in a Supply Chain. International Journal of Manufacturing Technology and Management, 1 (1), 79-93

Maupa, Haris. 2004. Faktor-Faktor yang Menentukan Pertumbuhan Usaha Kecil di Sulawesi Selatan. Disertasi Program Pascasarjana Universitas Hasanudin. Tidak dipublikasikan.

Mirza. 2011. Pengaruh Lingkungan Eksternal dan Lingkungan Internal terhadap Strategi Bersaing dan Strategi Kemitraan Serta Dampaknya Pada Keunggulan Bersaing dan Implikasinya Pada Kinerja Industri Kecil dan Menengah di Sumatra Barat. Disertasi. Universitas Padjadjaran. Bandung.

Peraturan Daerah Provinsi Jawa Barat Nomor 10 Tahun 2010 tentang Pemberdayaan dan Pengembangan Koperasi, Usaha Mikro, Kecil dan Menengah (Lembaran Daerah Provinsi Jawa Barat Tahun 2010 Nomor 10 Seri E Tambahan Lembaran Daerah Provinsi Jawa Barat Nomor 76)

Peraturan Daerah Provinsi Jawa Barat Nomor 8 Tahun 2011 tentang Pengelolaan Dana Bergulir Bagi Usaha Mikro dan Kecil.

Peraturan Gubernur Jawa Barat Nomor 57 Tahun 2011 tentang Petunjuk Pelaksanaan Peraturan Daerah Nomor 8 Tahun 2011 tentang Pengelolaan Dana Bergulir Bagi Usaha Mikro dan Kecil.

Pillay. 2006. The Internal And External Environment For Small Business Growth In Pietermaritzburg." 
Bulletin of Indonesian Economic Studies, Vol. 47, No. 2. Australian National University. Canberra.

Rahayu, Agus. 2004. Pengaruh Kekuatan Lingkungan Mikro dan Lingkungan Internal Terhadap Strategi Pemasaran serta Dampaknya pada Hasil Penjualan. Disertasi- Universitas Padjadjaran Bandung.

Rizal, K. 2003. Pengaruh Lingkungan Eksterrnal dan Internal terhadap Fungsi-fungsi Manajemen Sumber Daya Manusia dalam Mencapai Kinerja Perusahaan. Disertasi - Universitas Padjadjaran Bandung.

Rudberg, M.\& Olhager, J. 2003. Manufacturing Network and Supply Chain: an Operation Strategy Perspective. Omega.

Rusyani, Erni. 2004. Pengaruh Budaya Organisasi, Orientasi Etika, Orientasi Strategik dan Implementasi Strategi Terhadap Kinerja Perusahaan Manufaktur. Disertasi - Universitas Padjadjaran Bandung.

Sulastini, 2004. Faktor Eksternal dan Internal yang mempengaruhi Keberhasilan Kemitraan Koperasi dengan Usaha Pertambangan Batubara Skala kecil. Disertasi - Universitas Padjadjaran Bandung.

Sulistyo, Heru dan Ardian Adiatma (2011). Model Optimalisasi Kemitraan UKM (Usaha Kecil Menengah) dan BUMN (Badan Usaha Milik Negara) Melalui Program Kemitraan dan Bina Lingkungan (PKBL) untuk Meningkatkan Kinerja UKM. RIPTEK Vol.5 No.II Tahun 2011 Hal: $25-$ 40. Bappeda Kota Semarang, Semarang.

Suryana, 2003. Kewirausahaan: Pedoman Praktis,
Kiat dan Proses Menuju Sukses. Salemba Empat. Jakarta.

Suryoto, 2008. Pengaruh Lingkungan Eksternal dan Internal terhadap Kemitraan dan Kinerja Usaha Kecil (Survey pada Industri Mie Skala Kecil di Jawa Tengah). Disertasi-Universitas Padjadjaran Bandung.

Sutopo, Indi. 2011. Produktivitas dan Ketahanan Bisnis Industri Kecil (studi empiris industri batik tulis Trusmi Kecamatan Plered Kabupaten Cirebon). Jurnal Dinamika Keuangan dan Perbankan, vol 3 No 1. Fakultas Ekonomi Universitas Islam Indonesia. Yogyakarta.

Undang-undang Republik Indonesia Nomor 20 tahun 2008 tentang Usaha Mikro, Kecil dan Menengah.

Velasques, Manuel. G. 2002. Business ethic: Concepts and Cases, 5 th ed. Prentice-Hall. P 13

Wheelen, Thomas L.; Alan N Hoffman; Charles E. Bamford. 2015. Strategic Management and Business and Policy. Globalization, Innovation, and Sustainablity, 14th edition Pearson Education Limited.

Wijayanto, Setyo Hari. 2007. Structural Equation Modeling dengan Lisrel 8.8 Konsep dan Tutorial. Graha Ilmu. Yogyakarta.

Wilkinson, B., 2002, Small, Micro, and Medium Enterprise Development: Expanding the Option for Debt and Equity Finance. Financial Sector Workshop, National Economic Development and Labour Council (NEDLAC), Johanesburg, South Africa, Iris, April 6. 